\title{
Total body potassium in cor pulmonale
}

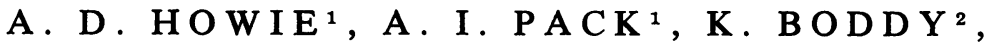 \\ and MAUREEN MAHAFFEY ${ }^{2}$
}

Centre for Respiratory Investigation, Glasgow Royal Infirmary, Glasgow G4 OSF ${ }^{1}$ and Scottish Universities Research and Reactor Centre, East Kilbride, Glasgow G79 0QU $U^{2}$

\begin{abstract}
Howie, A. D., Pack, A. I., Boddy, K., and Mahaffey, Maureen (1976). Thorax, 31, 708-712. Total body potassium in cor pulmonale. Total body potassium was measured in 12 patients with cor pulmonale, by determination of potassium-40, a naturally occurring radioisotope. In all subjects the observed value of total body potassium showed no significant depletion when compared with that predicted from height and age. All previous studies in similar groups of patients have been confined to the estimation of exchangeable potassium by the technique of isotope dilution. Results using the latter technique have shown gross potassium depletion. It is suggested that the apparent disparity between total body potassium and exchangeable potassium could be explained by the requirement for a longer equilibration period when using isotope dilution techniques in patients who are in a chronic hypoxaemic state.
\end{abstract}

Studies of body electrolyte composition in patients suffering from chronic airway obstruction have suggested that gross potassium depletion can occur. These studies have been confined to the measurement of exchangeable potassium $(\mathrm{Ke})$ by the technique of isotope dilution after the administration of potassium-42 $\left({ }^{42} \mathrm{~K}\right)$, which has a half-life of 12.4 hours (Bauer et al., 1966; Telfer et al., 1968; Schloerb et al., 1970; Campbell et al., 1975; Telfer, Weiner, and Merrill, 1975).

The interpretation of the results obtained by the isotope dilution technique is dependent on equilibration having been reached between the administered radioactive isotope and the native potassium. In the present study, the problem of equilibration was avoided by directly measuring the total body potassium (TBK) with a wholebody counter in a group of patients with cor pulmonale. The results were compared with predicted normal values.

\section{PATIENTS}

Twelve subjects, 11 men and one woman, were investigated. All had established irreversible airway obstruction, judged from spirometric testing, and chronic bronchitis according to the Medical Research Council questionnaire on respiratory symptoms (Medical Research Council, 1960). Their mean age was 58.8 (range $49-75$ ) years. All had previously had at least one episode of acute respiratory failure complicated by raised jugulag venous pressure and peripheral oedema, but they were in a chronic compensated state of the respiratory disease and free from oedema. Sub? jects with a blood urea greater than $10 \mathrm{mmol} / \frac{1}{3}$ were excluded. Ten patients were receiving drug therapy which was discontinued 12 hours before the study. Medications included digoxin, fruse mide, Slow-K, spironolactone, beclomethasonew salbutamol, and thyroxine. The patient on be clomethasone had established irreversible airwa obstruction with an $\mathrm{FEV}_{1} / \mathrm{FVC}$ ratio of $30 \%$ before and after bronchodilators. It was, there fore, thought to be justified to include her in ouw series. The subject on thyroxine was clinically and biochemically euthyroid, and thus there is no reason to suspect that this would alter the results. All patients were active and ambulant and had been on their usual diet and fluid intake beforid the beginning of the study. The clinical data ar\& shown in Table I.

\section{TEST PROCEDURES}

Total body potassium was measured using the Merlin mobile whole-body monitor (Boddy, $1967 \mathrm{~d}$ with a sodium iodide detector, $29 \cdot 2 \mathrm{~cm}$ diameter by $10.2 \mathrm{~cm}$ deep. A shadow-shield surrounded the detector housed in a central turret. The shield $\frac{B}{O}$ 
T A B L E I

CLINICAL FEATURES OF PATIENTS INCLUDED IN SIUDY

\begin{tabular}{|c|c|c|c|c|c|c|c|c|c|}
\hline Patient & $\underset{\text { (years) }}{\text { Age }}$ & $\begin{array}{c}\text { Height } \\
(\mathrm{cm})\end{array}$ & $\begin{array}{c}\text { Weight } \\
(\mathbf{k g})\end{array}$ & Sex & Diagnosis & Drug Therapy & $\begin{array}{c}\text { Duration } \\
\text { of Diuretic } \\
\text { Therapy } \\
\text { (years) }\end{array}$ & $\begin{array}{c}\text { FVC } \\
\text { (litres) }\end{array}$ & $\begin{array}{r}\text { FEV, } \\
\text { (litres) }\end{array}$ \\
\hline $\begin{array}{c}1 \\
2 \\
3 \\
4 \\
5 \\
6 \\
7 \\
8 \\
9 \\
10 \\
11 \\
12 \\
\text { Mean }\end{array}$ & $\begin{array}{l}63 \\
61 \\
62 \\
50 \\
49 \\
49 \\
59 \\
57 \\
59 \\
64 \\
75 \\
58 \\
58 \cdot 8\end{array}$ & $\begin{array}{l}162 \cdot 6 \\
163 \cdot 3 \\
182 \cdot 9 \\
167 \cdot 6 \\
179 \cdot 1 \\
160 \cdot 7 \\
167 \cdot 6 \\
139 \cdot 7 \\
161 \cdot 3 \\
170 \cdot 2 \\
170 \cdot 2 \\
177 \cdot 8 \\
166.9\end{array}$ & $\begin{array}{l}56 \cdot 7 \\
51 \cdot 3 \\
81 \cdot 2 \\
81 \cdot 6 \\
75 \cdot 8 \\
64 \cdot 4 \\
46 \cdot 8 \\
48 \cdot 4 \\
56 \cdot 0 \\
51 \cdot 9 \\
73 \cdot 0 \\
80 \cdot 7 \\
64 \cdot 0\end{array}$ & $\begin{array}{l}\mathbf{M} \\
\mathbf{M} \\
\mathbf{M} \\
\mathbf{M} \\
\mathbf{M} \\
\mathbf{M} \\
\mathbf{M} \\
\mathbf{F} \\
\mathbf{M} \\
\mathbf{M} \\
\mathbf{M} \\
\mathbf{M}\end{array}$ & $\begin{array}{l}\text { CB } \\
\text { CB } \\
\text { CB } \\
\text { CB } \\
\text { CB } \\
\text { CB } \\
\text { CB } \\
\text { CB } \\
\text { CB } \\
\text { CB } \\
\text { CB } \\
\text { CB }\end{array}$ & $\begin{array}{l}\text { Digoxin, Frusemide } 40 \mathrm{mg} \\
\text { Frusemide } 40 \mathrm{mg} \text {, Slow-K } \\
\text { Frusemide } 40 \mathrm{mg} \text {, Slow-K } \\
\text { Frusemide } 40 \mathrm{mg} \text {, Slow-K } \\
\overline{-} \\
\text { Frusemide } 40 \mathrm{mg} \text {, Slow-K } \\
\text { Salbutamol, Beclomethasone } \\
\text { Digoxin, Frusemide } 80 \mathrm{mg} \text {, Slow-K } \\
\text { Salbutamol } \\
\text { Frusemide } 40 \text { mg, Slow-K } \\
\text { Salbutamol, Thyroxine }\end{array}$ & $\begin{array}{r}4 \\
4 \\
3 \\
-\frac{2}{5} \\
5 \\
1\end{array}$ & $\begin{array}{l}1 \cdot 29 \\
2 \cdot 66 \\
3 \cdot 40 \\
2 \cdot 90 \\
2 \cdot 97 \\
1 \cdot 82 \\
1 \cdot 62 \\
1 \cdot 16 \\
1.98 \\
3 \cdot 30 \\
1 \cdot 70 \\
2 \cdot 57\end{array}$ & $\begin{array}{l}0.59 \\
1.22 \\
0.92 \\
1.39 \\
0.86 \\
0.69 \\
0.63 \\
0.36 \\
0.83 \\
1 \cdot 29 \\
0.65 \\
0.92\end{array}$ \\
\hline
\end{tabular}

${ }^{1} \mathrm{CB}=$ chronic bronchitis.

$10 \mathrm{~cm}$ thick lead bricks with a total weight of less than $8000 \mathrm{~kg}$. The patient, lying supine on a motorized couch, passed beneath the detector and was scanned from head to feet. The output was taken to a TMC 400-channel pulse height analyser. After printout of the accumulated data, the patient adopted the prone position, the direction of travel of the couch was reversed, and the patient was scanned from feet to head. The data were again recorded, and mean values were obtained for the two positions. The sensitivity obtained was comparable with that of the conventional steel or lead room monitors. The subject counting rate in the potassium- 40 photopeak was expressed as millimoles of potassium without the administration of a radioactive isotope using the procedure described by Boddy et al. (1971). The estimated coefficient of variation of this procedure was shown to be $3.9 \%$ for a subject having $3600 \mathrm{mmol}$ of potassium.

Expected total body potassium for each subject was estimated from height and age, and age, height, and weight using the regression equations derived for a healthy population (Boddy et al., 1972a). The equations are:

(a) Total body potassium based on height and age:

Males: $\mathrm{mmol}$ potassium $=$

$(53.02 \times$ height in $\mathrm{cm})-(9.74 \times$ age in years $)$ $-5305$

Females: $\mathrm{mmol}$ potassium $=$

(33.63 $\times$ height in $\mathrm{cm})-(7.73 \times$ age in years $)$ $-2727$

(b) Total body potassium based on height, weight, and age:
Males: $\mathrm{mmol}$ potassium $=$

$(23.96 \times$ weight in $\mathrm{kg})+(35.15 \times$ height in $\mathrm{cm})-(12.09 \times$ age in years $)-3762$

Females: $\mathrm{mmol}$ potassium $=$

$(14.76 \times$ weight in $\mathrm{kg})+(22.07 \times$ height in $\mathrm{cm})-(9.05 \times$ age in years $)-1669$

The standard deviation from regression for height and age are $9.3 \%$ for males and $8.8 \%$ for females, and for height, weight, and age are $7 \cdot 3 \%$ for males and $7 \cdot 8 \%$ for females.

The measured total body potassium in each patient was compared with the predicted values using a modification of the $\mathbf{z M}$ test to establish statistical significance, or otherwise, of the difference.

Blood for blood gas and plasma electrolyte estimation was obtained from an indwelling cannula inserted into the brachial artery. Each patient was rested in the sitting position for at least 15 minutes. Two arterial samples were taken at 30-minute intervals to ensure that stable results had been obtained. Informed consent was obtained from all patients in the study.

\section{RESULTS}

Blood gas measurements (Table II) revealed hypoxaemia in all the patients $\left(\mathrm{PaO}_{2}<9.8 \mathrm{kPa}\right)$ with a mean $\mathrm{PaO}_{2}$ of $7.43 \mathrm{kPa}$. The arterial carbon dioxide tension $\left(\mathrm{PaCO}_{2}\right)$ was frequently increased, but in all patients the plasma potassium was within normal limits. The values obtained for total body potassium, as measured by the wholebody monitor and those calculated from height and age, and height, weight, and age, are shown in Table III along with the relevant anthropo- 
T A B L E I I

MEASUREMENTS OF ARTERIAL BLOOD GASES AND ELECTROLYTES

\begin{tabular}{|c|c|c|c|c|c|c|c|c|}
\hline \multirow{2}{*}{ Patient } & \multirow{2}{*}{$\mathrm{pH}$} & \multirow{2}{*}{$\underset{(\mathrm{kPa})}{\mathrm{PaO}_{2}}$} & \multirow{2}{*}{$\begin{array}{c}\mathrm{PaCO}_{2} \\
(\mathrm{kPa})\end{array}$} & \multicolumn{5}{|c|}{ Plasma Electrolytes (mmoles/l) } \\
\hline & & & & $\mathbf{K}$ & $\mathrm{Na}$ & $\mathrm{Cl}$ & $\mathrm{HCO}_{3}$ & Urea \\
\hline $\begin{array}{r}1 \\
2 \\
3 \\
4 \\
5 \\
6 \\
7 \\
8 \\
9 \\
10 \\
11 \\
12\end{array}$ & $\begin{array}{l}7 \cdot 39 \\
7 \cdot 48 \\
7 \cdot 41 \\
7 \cdot 38 \\
7 \cdot 42 \\
7 \cdot 34 \\
7 \cdot 37 \\
7 \cdot 36 \\
7 \cdot 43 \\
7 \cdot 40 \\
7 \cdot 49 \\
7 \cdot 40\end{array}$ & $\begin{array}{l}6 \cdot 74 \\
9 \cdot 02 \\
9 \cdot 19 \\
6 \cdot 82 \\
7 \cdot 97 \\
5 \cdot 15 \\
5 \cdot 80 \\
6 \cdot 72 \\
5 \cdot 56 \\
9 \cdot 76 \\
6 \cdot 98 \\
9 \cdot 47\end{array}$ & $\begin{array}{l}7 \cdot 12 \\
5 \cdot 92 \\
6 \cdot 13 \\
6 \cdot 90 \\
4 \cdot 91 \\
7 \cdot 00 \\
9 \cdot 31 \\
8 \cdot 41 \\
6 \cdot 44 \\
6 \cdot 07 \\
5 \cdot 72 \\
5 \cdot 60\end{array}$ & $\begin{array}{l}4 \cdot 2 \\
3.9 \\
3 \cdot 8 \\
4 \cdot 5 \\
4 \cdot 0 \\
4 \cdot 3 \\
3 \cdot 6 \\
4 \cdot 2 \\
3 \cdot 8 \\
4 \cdot 0 \\
3 \cdot 8 \\
3 \cdot 6\end{array}$ & $\begin{array}{l}140 \\
141 \\
140 \\
142 \\
139 \\
142 \\
139 \\
143 \\
140 \\
141 \\
140 \\
142\end{array}$ & $\begin{array}{r}100 \\
102 \\
102 \\
100 \\
101 \\
102 \\
92 \\
99 \\
93 \\
105 \\
98 \\
100\end{array}$ & $\begin{array}{l}31 \\
28 \\
23 \\
26 \\
30 \\
34 \\
29 \\
36 \\
27 \\
26 \\
28\end{array}$ & $\begin{array}{l}3 \cdot 9 \\
6 \cdot 5 \\
6 \cdot 2 \\
4 \cdot 0 \\
4 \cdot 6 \\
5 \cdot 7 \\
6 \cdot 2 \\
4 \cdot 2 \\
5 \cdot 9 \\
5 \cdot 8 \\
8 \cdot 9 \\
6 \cdot 1\end{array}$ \\
\hline
\end{tabular}

T A B L E I I I

MEASUREMENT OF TOTAL BODY POTASSIUM IN 12 PATIENTS WITH CHRONIC COR PULMONALE

\begin{tabular}{|c|c|c|c|c|c|}
\hline Patient & $\underset{(\mathrm{mmol})}{\text { Observed TBK }}$ & $\begin{array}{l}\text { Predicted TBK (mmol) } \\
\text { (height, age) }\end{array}$ & $\mathbf{P}^{1}$ & $\begin{array}{l}\text { Predicted TBK (mmol) } \\
\text { (height, weight, age) }\end{array}$ & $\mathbf{P}^{1}$ \\
\hline $\begin{array}{c}1 \\
2 \\
3 \\
4 \\
5 \\
6 \\
7 \\
8 \\
9 \\
10 \\
11 \\
12 \\
\text { Mean }\end{array}$ & $\begin{array}{l}2920 \\
2527 \\
3241 \\
3732 \\
3614 \\
3024 \\
2487 \\
2245 \\
3063 \\
2726 \\
3079 \\
3918 \\
3048\end{array}$ & $\begin{array}{l}2701 \\
2760 \\
3788 \\
3095 \\
3714 \\
2736 \\
3005 \\
1529 \\
2673 \\
3095 \\
2987 \\
3558 \\
2970\end{array}$ & $\begin{array}{l}0.53 \\
0.50 \\
0.14 \\
0.06 \\
0.77 \\
0.40 \\
0.13 \\
0.005 \\
0.26 \\
0.29 \\
0.80 \\
0.31\end{array}$ & $\begin{array}{l}2550 \\
2471 \\
3865 \\
3481 \\
3757 \\
2834 \\
2537 \\
1611 \\
2537 \\
2691 \\
3064 \\
3721 \\
2927\end{array}$ & $\begin{array}{l}0.18 \\
0.84 \\
0.04 \\
0.36 \\
0.60 \\
0.49 \\
0.86 \\
0.005 \\
0.06 \\
0.90 \\
0.96 \\
0.48\end{array}$ \\
\hline
\end{tabular}

TBK = total body potassium; Predicted values for TBK are calculated from the data of Boddy et al (1972a).

${ }^{1} \mathbf{P}$ based on a modification of the $\mathrm{zM}$ test (see text).

metric data. In each case the observed total body potassium was not significantly less than the predicted value calculated from the height and age, and in only one subject (no. 3) was the observed level significantly less $(P<0.05)$ than the value predicted from height, weight, and age. In addition, in one patient (no. 8) the observed total body potassium was significantly greater than predicted, which suggests that the sample of patients studied was comparable with the normal population.

If the eight patients in respiratory failure with a $\mathrm{PaO}_{2}$ of less than $8 \mathrm{kPa}$ are considered separately from the whole group, the observed total body potassium is still not significantly less than that predicted from height and age.

\section{DISCUSSION}

In this study we have shown that the total body potassium in all subjects was not significantly less than that predicted from height and age. This finding was surprising as in all previous reports where exchangeable potassium had been measured in similar groups of patients it was found to be르 significantly less than predicted normal valueš (Bauer et al., 1966; Telfer et al., 1968; Schloeris et al., 1970; Campbell et al., 1975; Telfer et al. 1975). Our patients were clinically similar to those included in these other series and had similak blood gas abnormalities (Table IV).

The equilibration period used in these studies was 24 and 48 hours. Furthermore, as a result of demonstrating low exchangeable potassium inf patients with chronic respiratory failure, Schloer et al. (1970) proceeded to correct the apparen\& potassium deficiency with potassium supplement $\$$ while admitting that there was no evidence of functional improvement. It is, therefore, of corfo siderable clinical importance to examine the relevance of low exchangeable potassium in patients with chronic airways obstruction, especially in the light of our results.

The difference between the results obtained fo total body potassium and exchangeable potassiun? 
T A B L E I V

COMPARISON OF ARTERIAL BLOOD GASES IN PATIENTS STUDIED BY DIFFERENT AUTHORS

\begin{tabular}{|c|c|c|c|c|c|c|c|c|c|}
\hline \multirow{2}{*}{ Authors } & \multicolumn{3}{|c|}{$\mathrm{PaO}_{2}(\mathbf{k P a})$} & \multicolumn{3}{|c|}{$\mathrm{PaCO}_{2}(\mathrm{kPa})$} & \multicolumn{3}{|c|}{$\mathbf{p H}$} \\
\hline & Mean & & SD & Mean & & SD & Mean & & SD \\
\hline $\begin{array}{l}\text { Schloerb et al (1970) } \\
\text { Telfer et al (1975) } \\
\text { Campbell et al (1975) } \\
\text { Present study }\end{array}$ & $\begin{array}{l}8 \cdot 57 \\
7 \cdot 18 \\
6 \cdot 80 \\
7 \cdot 43\end{array}$ & $\begin{array}{l} \pm \\
\pm \\
\pm \\
\pm\end{array}$ & $\begin{array}{l}2 \cdot 11 \\
1 \cdot 33 \\
1 \cdot 10 \\
1 \cdot 60\end{array}$ & $\begin{array}{l}6 \cdot 89 \\
6 \cdot 65 \\
7 \cdot 40 \\
6 \cdot 63\end{array}$ & $\begin{array}{l} \pm \\
\pm \\
\pm \\
\pm\end{array}$ & $\begin{array}{l}2 \cdot 03 \\
1 \cdot 46 \\
1 \cdot 10 \\
1 \cdot 23\end{array}$ & $\begin{array}{l}7 \cdot 42 \\
7 \cdot 40 \\
7 \cdot 41\end{array}$ & $\begin{array}{c}\frac{ \pm}{ \pm} \\
\text { Not stated } \\
\pm\end{array}$ & $\begin{array}{l}0.03 \\
0.05 \\
0.01\end{array}$ \\
\hline
\end{tabular}

in cor pulmonale could be explained by the need for a longer period of equilibration when studying exchangeable potassium by the isotope dilution technique. This explanation is supported by the work of Telfer et al. (1975). The value for exchangeable potassium which they obtained at 48 hours was $20 \%$ greater than that at 24 hours but still significantly less than the predicted normal values. This finding is analogous to that of Boddy et al. (1972b) in patients with chronic renal failure. They compared total body potassium determined by whole-body monitoring with exchangeable potassium using ${ }^{43} \mathrm{~K}$ which has a half-life of 22 hours, in the same group of patients. Though total body potassium was within the normal range, the value for exchangeable potassium at 64 hours was $2.3 \%$ greater than that at 48 hours and $25.2 \%$ greater than that at 24 hours but still $14 \%$ less than the predicted normal value.

It is possible that the exchangeable potassium is a smaller fraction of the total body potassium in patients with cor pulmonale than in healthy subjects. Studies in normal subjects have suggested that exchangeable potassium is $92 \%$ to $97 \%$ of total body potassium (Talso et al., 1960; Remenchik and Miller, 1962; Surveyor and Hughes, 1968), whereas in patients with chronic renal failure, for example, exchangeable potassium at 24 hours was $60 \cdot 7 \%$ of the total body potassium, and at 64 hours was $85.9 \%$.

It is unlikely that diuretics or other drug therapy affected our results. Dargie et al. (1974) showed that patients with essential hypertension and normal renal function, who had been on $40 \mathrm{mg}$ frusemide daily with or without potassium supplementation, showed no evidence of depletion of total body potassium.

Other workers have suggested that the low values obtained for exchangeable potassium could be explained by changes in body weight. Campbell et al. (1975) observed body weight and exchangeable potassium in patients with cor pulmonale after treatment of the acute illness when the oedema had disappeared but while the patients were still on oxygen therapy. Six patients were then re-examined two to three months later during convalescence. They concluded that the low values of exchangeable potassium obtained could be explained by loss of tissue mass. However, this does not explain why exchangeable potassium remained reduced in convalescence even though in most instances weight gain was almost complete. In two patients in particular there was an increase in dry body weight in convalescence but a further reduction in exchangeable potassium from the value obtained during the initial assessment. If low exchangeable potassium in patients with cor pulmonale is to be explained mainly on the basis of tissue loss, then it is surprising that in all our patients the total body potassium showed no significant depletion when compared with normal values predicted from height and age.

The results obtained for total body potassium and exchangeable potassium in patients with cor pulmonale are conflicting. It may be that a longer equilibration period is required or that the exchangeable potassium fraction is smaller in patients with chronic respiratory disease, and that these are the main reasons for the disparity between total body potassium measured in the whole-body monitor and exchangeable potassium measured by the isotope dilution technique.

\section{REFERENCES}

Bauer, F. K., Telfer, N., Herbst, H. H., Austin, R. C., and Hetter, B. (1966). Hyponatremia and increased exchangeable sodium in chronic obstructive lung disease. American Journal of Medical Science, 250, 245.

Boddy, K. (1967). A high sensitivity shadow-shield whole body monitor with scanning-bed and tilting chair geometries, incorporated in a mobile laboratory. British Journal of Radiology, 40, 631.

Boddy, K., King, C., Hume, R., and Weyers, E. (1972a). The relation of total body potassium to height, weight, and age in normal adults. Journal of Clinical Pathology, 25, 512. 
Boddy, K., King P. C., Lindsay, R. M., Winchester, J., and Kennedy, A. C. (1972b). Exchangeable and total body potassium in patients with chronic renal failure. British Medical Journal, 1, 140.

Boddy, K., King, P. C., Tothill, P., and Strong, J. A. (1971). Measurement of total body potassium with a shadow shield wholebody counter: calibration and errors. Physics in Medicine and Biology, 16, 275.

Campbell, R. H. A., Brand, H. L., Cox, J. R., and Howard, P. (1975). Body weight and body water in chronic cor pulmonale. Clinical Science and Molecular Medicine, 49, 323.

Dargie, H. J., Boddy, K., Kennedy, A. C., King, C., Read, P. R., and Ward, D. M. (1974). Total body potassium in long-term frusemide therapy: is potassium supplementation necessary? British Medical Journal, 4, 316.

Medical Research Council (1960). Standardized questionaries on respiratory symptoms. British Medical Journal, 2, 1665.

Remenchik, A. P. and Miller, C. E. (1962). In Wholebody Counting: Proceedings of the Symposium on Whole-Body Counting, p. 331. International Atomic Energy Agency, Vienna.
Schloerb, P. R., King, C. R., Kerby, G., and Ruth, W. E. (1970). Potassium depletion in patientso with chronic respiratory failure. American $R e \overline{\bar{n}}$ view of Respiratory Disease, 102, 53.

Surveyor, I. and Hughes, D. (1968). Discrepancies between whole-body potassium content and ex-s changeable potassium. Journal of Laboratory and $\rightarrow$ Clinical Medicine, 71, 464.

Talso, P. J., Miller, C. E., Carballo, A. J., and $\vec{\omega}$ Vasquez, I. (1960). Exchangeable potassium as aO parameter of body composition. Metabolism, $9 \overrightarrow{\mathrm{g}}$ 456.

Telfer, N., Bauer, F. K., Mickey, M. R., and Herbst $\stackrel{\omega}{\rightarrow}$ H. H. (1968). Body composition in chronic ob? structive pulmonary disease. American Review of Respiratory Disease, 98, 640.

Telfer, N., Weiner, J. M., and Merrill, Q. (1975)을 Distribution of sodium and potassium in chronicobstructive pulmonary disease. American Revieno of Respiratory Disease, 111, 166.

Requests for reprints to: Dr. A. D. Howie, Centre्ष्ठ for Respiratory Investigation, Royal Infirmary Glasgow G4 OSF. 